Document downloaded from:

http://hdl.handle.net/10251/101826

This paper must be cited as:

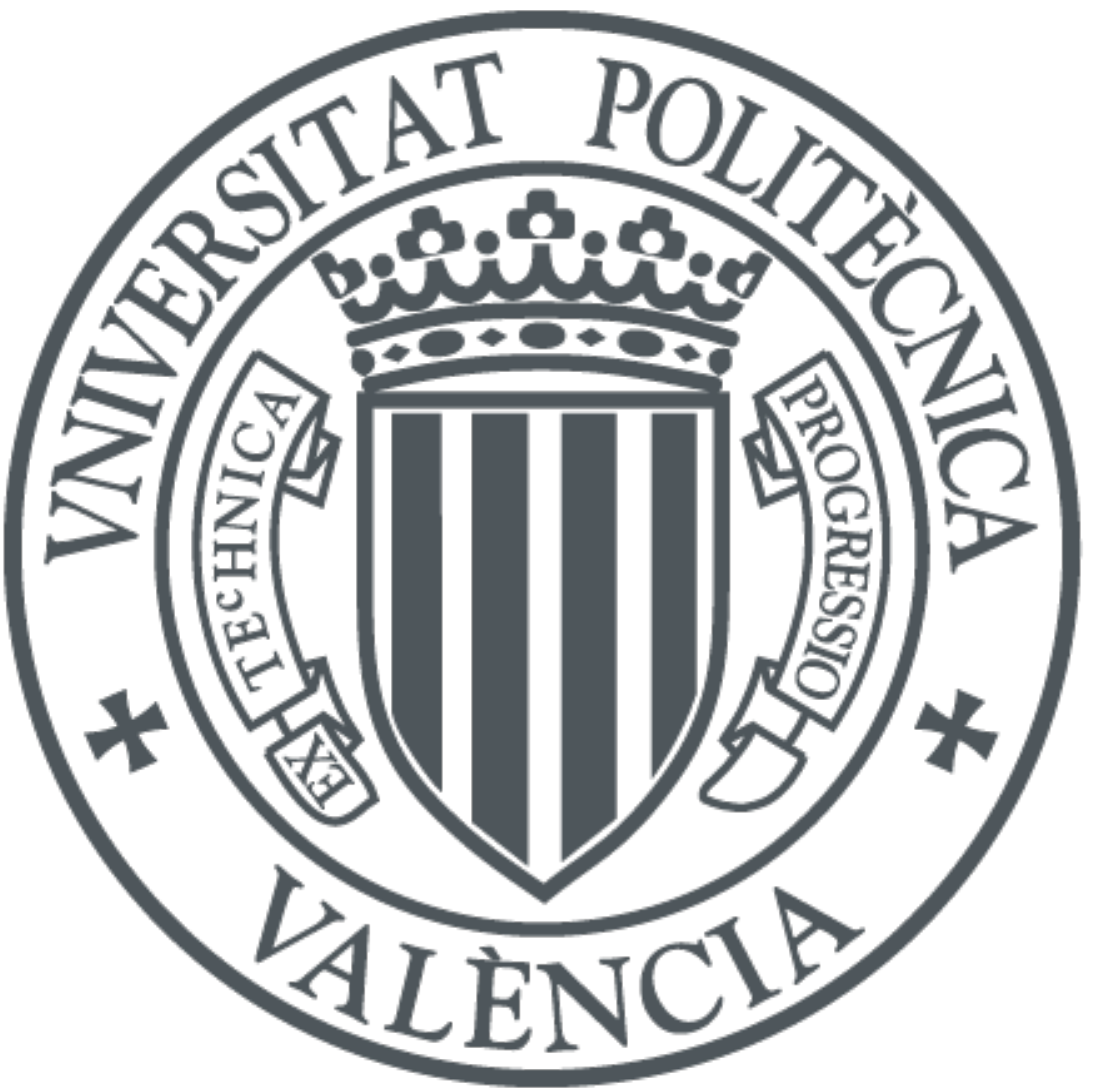

The final publication is available at

http://doi.org/10.1002/ps.4289

Copyright John Wiley \& Sons

Additional Information 


\section{Lures for Red Palm Weevil trapping systems: aggregation pheromone and}

\section{synthetic kairomone}

3

4 Sandra Vacas ${ }^{1}$, Ourania Melita ${ }^{2}$, Antonios Michaelakis ${ }^{2}$, Panagiotis Milonas ${ }^{2}$, Roxana Minuz ${ }^{3}$,

5 Paola Riolo ${ }^{3}$, Mohamed Kamal Abbass ${ }^{4}$, Paolo Lo Bue ${ }^{5}$, Stefano Colazza ${ }^{5}$, Ezio Peri ${ }^{5}$, Victoria

6 Soroker $^{6}$, Yaara Livne ${ }^{7}$, Jaime Primo ${ }^{1}$, Vicente Navarro-Llopis ${ }^{1}$

7

$8{ }^{1}$ Centro de Ecología Química Agrícola - Instituto Agroforestal del Mediterráneo, Universitat Politècnica

9 de València, Valencia (Spain)

$10{ }^{2}$ Department of Entomology \& Agricultural Zoology, Benaki Phytopathological Institute, Kifissia

11 (Greece)

$12{ }^{3}$ Dipartimento di Scienze Agrarie, Alimentari ed Ambientali, Università Politecnica delle Marche,

13 Ancona (Italy)

$14 \quad{ }^{4}$ Plant Protection Research Institute, Agricultural Research Center, Giza (Egypt)

$15 \quad{ }^{5}$ Dipartimento di Scienze Agrarie e Forestali, Università degli Studi di Palermo, Palermo (Italy)

$16{ }^{6}$ Agricultural Research Organization, the Volcani Center, Bet-Dagan (Israel)

177 Eden Experimental Farm, Emeq Beit Sheaan (Israel)

19 Correspondence: Sandra Vacas, Centro de Ecología Química Agrícola - Instituto Agroforestal del

20 Mediterráneo, Universidad Politécnica de Valencia. Camino de Vera s/n, edificio 6C, $5^{\text {a }}$ planta. 46022,

21 Valencia (Spain). E-mail: sanvagon@ ceqa.upv.es; tel: +34 963879058; fax: +34 963879059

22

23 Running title: Lures for Red Palm Weevil trapping systems 


\section{Abstract}

BACKGROUND: The optimization of the lure is essential for the implementation of trapping systems to control insect pests. In this work, the response of the red palm weevil (RPW), Rhynchophorus ferrugineus Olivier, to increasing emission rates of its aggregation pheromone (ferrugineol) and the efficacy of a convenient synthetic kairomone based on fermentation odors (ethyl acetate and ethanol) have been evaluated in different years and locations along the Mediterranean basin. RESULTS: In general, although capture data and emission had noticeable variability among locations, significantly less RPW were captured in pyramidal Picusan ${ }^{\circledR}$ traps with the lowest ferrugineol emission rates tested (0.6-3.8 mg/day $\left.{ }^{-1}\right)$. Captures increase rapidly with ferrugineol emission up to 4-5 $\mathrm{mg} \mathrm{day}^{-1}$; then, higher emission rates did not improve nor decrease captures, up to the highest emission rate tested of $50.9 \mathrm{mg} \mathrm{day}^{-1}$. Thus, there is no evidence of an optimum release rate corresponding with a maximum of RPW catches. Traps baited with the synthetic kairomone (1:3 ethyl acetate/ethanol) captured from 1.4 to 2.2 times more total weevils than traps baited only with ferrugineol. Moreover, in most of the locations, the synthetic blend was at least as effective as the local co-attractants used (plant material + molasses). CONCLUSIONS: Ferrugineol emission rate can vary in a wide range without affecting significantly RPW response. Co-attractants based on fermenting compounds, ethyl acetate and ethanol, are able to improve the attractant level of ferrugineol and could be employed to replace non-standardized natural kairomones in RPW trapping systems after further optimization of their proportions and doses.

44 Keywords Rhynchophorus ferrugineus, 4-methyl-5-nonanol, ethyl acetate, ethanol, mass trapping, monitoring 


\section{INTRODUCTION}

The use of trapping systems is an efficient technique to be included in any integrated pest management program (IPM) to control the red palm weevil (RPW), Rhynchophorus ferrugineus Olivier, by means of preventive and curative measures. Early detection and monitoring are essential to plan further actions against infestations, whereas mass trapping helps reducing population levels. Management of RPW by this mean has been widely employed throughout the Middle East and the effectiveness of the pheromonebased trapping for RPW was demonstrated. ${ }^{1}$ Later, results presented by Soroker et al. ${ }^{2}$ indicated that mass trapping could serve as a tool for controlling RPW in Israel and it is a key part of the IPM carried out in Saudi Arabia to protect palm crops. ${ }^{3}$ Semiochemical-based trapping systems for weevils had three main components: trap, aggregation pheromone and kairomone (co-attractant). Buried bucket traps are traditionally employed for these purposes but improvements (color, surface, retention system) and even new trap designs have been introduced in the last years. ${ }^{1,4-5}$ Regarding the attractant, Hallett et al. ${ }^{6}$ first reported identification and activity (both in electrophysiological and field tests) of the main compound of the RPW aggregation pheromone, 4-methyl-5-nonanol (ferrugineol). A second compound with electrophysiological activity, 4-methyl-5-nonanone (ferruginone), was also identified in the volatile extracts but field tests did not evidence pheromonal activity. The aggregation pheromone is emitted by the males of the species and attracts both sexes, with bias towards females, which is highly favorable for the mass trapping technique. The second component for weevil attraction is the kairomone; it has been demonstrated that natural palm baits have poor attractant power by themselves but strongly synergize the effect of the aggregation pheromone. ${ }^{7}$ The fermentation volatile compounds emitted by different host plant tissues have been studied through electrophysiological bioassays and have revealed that RPW antennae are responsive to many compounds, including the so called 'palm esters' ${ }^{8-9} \mathrm{RPW}$ attraction to these compounds has been also tested in field trials: Guarino et al. ${ }^{8}$ observed that a blend of the esters ethyl acetate and ethyl propionate improved catches in traps baited with pheromone and molasses, better than the individual esters. More recently, Vacas et al. ${ }^{9}$ found that RPW catches increased two-fold with the 1:3 ethyl acetate/ethanol blend compared to aggregation pheromone alone, even achieving $76 \%$ efficacy if compared to the total weevil catches obtained with a kairomonal co-attractant composed by $P$. canariensis palm stem and sugar molasses.

In general, sensitivity of pheromone-based monitoring and efficacy of mass trapping strategies is highly determined by pheromone emission rates. It has been widely described that pheromone release rate must 
be controlled because insect response could decrease below and above an optimum value. ${ }^{10-14}$ Besides, pheromone cost is a key parameter for the implementation of this kind of control methods; thus, optimum pheromone emission rates should be known to avoid pheromone waste. The pheromone dose-dependent behavior of RPW has been early evaluated by Hallet et al. ${ }^{6}$ in field experiments, in which bucket traps releasing $3 \mathrm{mg} \mathrm{day}^{-1}$ of ferrugineol captured significantly more weevils than traps with emission rate of 0.3 and $1 \mathrm{mg} \mathrm{day}^{-1}$.

Available literature dealing with RPW lures is focused on studies in a particular location and no common protocols are then described for implementation anywhere. The present work reports results obtained with the aim of establishing trapping protocols valid for most of the areas where RPW is present or susceptible to be invaded. For this purpose, the field tests reported herein were conducted with standard protocols in five different countries along the Mediterranean basin, covering a large geographical area. The response of the RPW to increasing ferrugineol emission rates was evaluated in field trials by comparing the number of weevils captured in pyramidal Picusan ${ }^{\circledR}$ traps baited with different types and numbers of ferrugineol dispensers. Similarly, to evaluate the potential of synthetic lures to replace the use of plant material to boost trap attractiveness, the efficacy of the synthetic co-attractant suggested in Vacas et al., ${ }^{9}$ a blend of ethyl acetate and ethanol, has been assessed relative to ethyl acetate alone or local reference coattractants (palm pieces and/or molasses).

\section{MATERIALS AND METHODS}

\subsection{Traps and dispensers}

The new design of pyramidal trap Picusan ${ }^{\circledR}$ (Sansan Prodesing SL, Náquera, Valencia, Spain), described in Vacas et al., ${ }^{5}$ was employed in all the field trials, the base of which was filled with 1.5-2 L water. Aggregation pheromone dispensers employed in our trials only used ferrugineol as aggregation pheromone due to the lack of evidences for pheromonal activity of ferruginone in the literature available ${ }^{6}$ and our own experience. The standard commercial aggregation pheromone dispenser employed in all the trials as reference was Pherosan RF (Sansan Prodesing SL, Náquera, Valencia, Spain), which is a polyethylene (PE) vial (18 mm diam. x $35 \mathrm{~mm}$ h.) loaded with $1 \mathrm{~g}$ of ferrugineol (98\% purity, sum of enantiomers). The response of RPW to different ferrugineol emission rates was studied by baiting traps with different types or numbers of pheromone dispensers. The lowest emission rate was provided in 2012 by $5-\mathrm{ml}$ Nalgene ${ }^{\mathrm{TM}}$ low-density polyethylene vials (LD-PE) (20 mm diam. x $25 \mathrm{~mm}$ h.) (Fisher Scientific 

dispenser was modified by different experimental means to slow down its emission and provide the lower emission rates. In particular, in 2013 the dispenser was modified with an adhesive tape coating (mod-RF 1), and in 2014, the dispenser was inserted inside a 12-ml Nalgene ${ }^{\mathrm{TM}}$ LD-PE vial (23 mm diam. x $36 \mathrm{~mm}$ h.) (Fisher Scientific SL, Madrid, Spain) (mod-RF 2). Previous to field installation, it was ascertained that Pherosan RF emission rate was effectively reduced by the mentioned modifications by studying the release profile of laboratory aged dispensers. The highest emission rates tested in each trial were obtained by baiting traps with 2, 3 or 4 Pherosan RF dispensers as described below. Synthetic kairomone dispensers (K) were 100-mL LD-PE bottles (Kartell SPA, Noviglio, Italy), loaded with $30 \mathrm{~mL}$ of the 1:3 ethyl acetate/ethanol blend in all the trials except in trial $\mathrm{K} 3$, where loading was mistaken and the 1:2 ratio was accidentally tested. Active ingredients were emitted through a 100 gauge LD-PE sheet attached to the top of the bottle. Same type of dispensers was loaded with $30 \mathrm{~mL}$ of ethyl acetate (EtAc) to test this compound alone in the kairomone trials.

\subsection{Release profile studies}

In parallel to the field trials, release profiles of the pheromone and kairomone dispensers were studied in each location. The gravimetric method was employed to assess the amount of ingredients released in relation to the aging time. Three additional dispensers of each type were aged under the same field conditions inside the same type of trap in each location and were weighed weekly in the laboratory on a precision balance $(0.0001 \mathrm{~g})$. Dispensers were aged during the corresponding study periods, from the beginning to the end of each field trial, according to dates in Tables 2 and 3. This was not performed in the kairomone trial conducted in Egypt (trial K1) due to technical difficulties. The weight differences over a period were referred to as the amount of ferrugineol or kairomone released from the dispenser. To obtain the mean emission level for each dispenser, recorded weights $(y)$ were fitted by polynomial regression with the independent variable $x$, number of ageing days, and its linear and quadratic effects were studied. When effect of the quadratic term was not significant ( $\mathrm{F}$ test at $\mathrm{P}>0.05)$, recorded weights fitted linear regression models, $y=\mathrm{a}+\mathrm{b} x$; thus, the slope of the linear model gave the mean release rate of the corresponding dispenser, which was assumed constant throughout the study period. In the case of the aggregation pheromone, it was previously ascertained by gas chromatography (GC-FID) that dispenser weight losses corresponded effectively to ferrugineol emission and not to degradation 
products. Similarly, for the ethyl acetate/ethanol dispensers, we checked the ratio in which the compounds were emitted. For this purpose, a GC/FID analysis of the remaining kairomone contained in the dispensers employed in some trials was performed and compared with the GC/FID analysis of the initial kairomone blends. All GC/FID analysis used a Clarus500 gas chromatograph from PerkinElmer (Wellesley, MA, USA) and injections were made onto a ZB-5MS column $(30 \mathrm{~m} \times 0.25 \mathrm{~mm} \times 0.25 \mu \mathrm{m}$; Phenomenex Inc., Torrance, CA, USA). Carrier gas was helium at $1.2 \mathrm{ml} / \mathrm{min}$ and detector temperature was set at $250^{\circ} \mathrm{C}$.

\subsection{Trials}

All of the trials were designed as randomized block assays and were carried out in the locations described in Table 1 and pointed out in Fig. 1. The revision of catches and rotation of traps were performed on a weekly basis. In all of the trials, the traps within each block were separated by at least $50 \mathrm{~m}$ and the distance between blocks was at least $200 \mathrm{~m}$.

\subsubsection{Aggregation pheromone trials}

In each trial (Table 2), each block consisted in four traps with different baits to provide four different ferrugineol emission rates. In trial P1, traps were baited with: (1) one 5-ml Nalgene ${ }^{\mathrm{TM}}$ LD-PE vial, (2) one Pherosan RF, (3) two Pherosan RF, and (4) three Pherosan RF dispensers. In trial P2, traps were baited with: (1) one mod-RF 1, (2) one Pherosan RF, (3) two Pherosan RF, and (4) four Pherosan RF dispensers. For the trials carried out during 2014 (trials P3-P6), traps were baited as described for trial P2, except for trap (1) which contained one mod-RF 2.

\subsubsection{Kairomone trials}

Four plots were arranged in each trial (Table 3) to test the synthetic kairomone blend ethyl acetate/ethanol, each of them consisting of 4 or 5 traps with the fifth corresponding to the use of the reference co-attractant employed in the local protocols (palm tissues and/or molasses). All traps were baited with one standard Pherosan RF dispenser, which were assumed to emit ferrugineol at release rates $\geq 4 \mathrm{mg} \mathrm{day}^{-1}$ according to previous studies. In general, each block included a trap baited with: (1) only one Pherosan RF dispenser (ph); (2) ph + 1 dispenser with the synthetic kairomone (ph+1K); (3) $\mathrm{ph}+2$ dispensers with the synthetic kairomone, to have a higher emission $(\mathrm{ph}+2 \mathrm{~K})$; (4) $\mathrm{ph}+1$ ethyl acetate dispenser (ph+EtAc); (5) ph + reference local co-attractant (the one which is commonly used in each location, as detailed in Table 3). Replacement of water and co-attractants was done every 5 weeks (after 
one complete trap rotation) in all locations except in Egypt, where it was done every two weeks due to a higher evaporation rate.

\subsection{Statistical analysis}

The number of total weevils captured in each trap recorded during each trapping period was divided by the number of days between dates to calculate the weevils per trap and day (WTD) index. Although more females than males were caught in general (female/male ratios $>1$ ), there was not remarkable difference in the responses by either sex and, thus, statistical analysis was performed with the total number of weevils captured.

To deal with non-homogeneous variance and data overdispersion, we used generalized linear model (GLM) techniques assuming quasi-Poisson error variance ${ }^{15}$ to compare the mean number of WTD captured in each trap. Once each model was fitted, the validity of the assumptions made was evaluated with the $\operatorname{plot}(\mathrm{glm}$.model) function by checking residuals distribution and the existence of patterns and outliers. For each trial, we constructed different models with the number of WTD as the dependent variable and the emission rate (trap), sampling date, block and their interactions as the explanatory variables (interaction trap $\mathrm{x}$ date $\mathrm{x}$ block was not significant in all cases). The significance of the explanatory variables was assessed by backward elimination from the model and subsequent comparison of the two models using the $\mathrm{F}$ test statistic. When significant effects were found the glht function in the multcomp package ${ }^{16}$ was used to perform Tukey HSD tests for post-hoc pairwise comparisons. All these statistical analyses were conducted with $\mathrm{R}$ (R version 3.1.0). ${ }^{17}$

To draw a general conclusion and study the existence of an optimum ferrugineol emission rate corresponding to a relative maximum of RPW captures, we followed the methodology employed in Vacas et al. ${ }^{12}$ Briefly, we applied a two-factor ANOVA (location and sampling date) using the $\log (\mathrm{x}+1)$ transformed captures of the whole data set (trials P1-P6). The residuals of this model still account for the variability of captures caused by ferrugineol emission, as this factor was not included in the ANOVA. Thus, these residuals were saved and used in a subsequent multiple regression analysis to study the existence of a relative maximum by checking the significance of the quadratic effect of the ferrugineol emission in a polynomial model. These analyses were performed using the Statgraphics Centurion XVI 16.2 package (StatPoint Technologies Inc., Warrenton, VA, USA). 


\subsection{Aggregation pheromone trials}

200 Ferrugineol dispensers employed in the different trials provided the mean emission rates given in Table 4.

201 As can be noticed, emission was variable among locations probably due to the local environmental

202 conditions. For example, trial P3 which began earlier in the season was affected by lower mean temperatures, obtaining the lowest ferrugineol emission rates tested.

204 Results of the trial conducted in Manises (Spain) in 2012 (trial P1), showed that ferrugineol emission significantly affected RPW captures (Table 5). Significantly less captures were obtained with the lowest emission rate tested $\left(2.6 \mathrm{mg} \mathrm{day}^{-1}\right)$ relative to the rest $(\mathrm{P}<0.04$, Tukey HSD test). Emission rates over 4.2 $\mathrm{mg} \mathrm{day}^{-1}$ did not significantly improve the attractiveness to RPW (Fig. 2- P1). Same result was obtained in Valencia (Spain) during summer 2013 (trial P2). When aggregation pheromone was released at rates from 5.5 up to $44.6 \mathrm{mg} \mathrm{day}^{-1}$ (Table 4), the emission rate did not have a significant effect on weevil captures (Table 5) (Fig. 2- P2).

When the same type of experiment was conducted in different locations during spring-summer 2014 (trials P3-P6), results showed that, in general, all the lowest pheromone release rates attracted significantly fewer weevils in the traps. In the trial conducted in Greece (trial P3), the emission rate had a significant effect on weevil captures (Table 5) and the lowest emission rate tested, $0.6 \mathrm{mg} \mathrm{day}^{-1}$, achieved significantly lower weevil captures (Fig. 2- P3). No significant differences were observed between emission rates ranging 2.7-10.8 $\mathrm{mg} \mathrm{day}^{-1}$ in trial P3 (P > 0.20, Tukey HSD test). This result also agrees with the experiment conducted in Israel (Fig. 2- P5), where RPW response was not significantly affected by ferrugineol emission rates ranging 2.1-32.4 $\mathrm{mg} \mathrm{day}^{-1}$ (Table 6). In contrast, in Italy (trial P4) and Spain (trial P6), the response threshold was somewhat different, as significantly lower total captures were obtained by emitting 2.6-3.8 $\mathrm{mg} \mathrm{day}^{-1}$ of ferrugineol (P < 0.04, Tukey HSD test) (Fig. 2 -P4 and P6). Besides ferrugineol emission, RPW catches were in general strongly affected by the other factors studied, block and date (Table 5), which is explained by the natural dispersion and seasonality of RPW. Although data variability was remarkable, same trend was observed in all trials for RPW response to the different ferrugineol emission rates. When trying to draw a general conclusion gathering the whole available data (trials P1-P6), multiple regression analysis showed that there is no definite optimum ferrugineol emission rate. After removing data variability due to time (date) and location by means of the two-way ANOVA (date: $\mathrm{F}_{26,654}=4.97, \mathrm{P}<0.001$; location $\mathrm{F}_{4,654}=41.83, \mathrm{P}<0.001$ ), multiple regression 
analysis performed with the residuals of the ANOVA as the dependent variable showed that the quadratic term of the emission did not have a significant effect $\left(P=0.28\right.$; model: $\left.\mathrm{R}^{2}=0.27\right)$ and, thus, there was no evidence of an optimum release rate corresponding with a maximum of RPW catches. However, the trend significantly fitted the logarithmic model depicted in Fig. $3\left(\mathrm{P}=0.013\right.$; model $\left.\mathrm{R}^{2}=0.51\right)$, suggesting that captures increase rapidly up to release rates of about 4-5 $\mathrm{mg} \mathrm{day}^{-1}$ and slowly over this threshold.

\subsection{Kairomone trials}

Kairomone dispensers provided the mean emission rates listed in Table 4, which varied among trials attending to local environmental conditions. GC-FID analysis also revealed that ethyl acetate/ethanol were emitted in a 2:1 ratio in trial $\mathrm{K} 3$, where $\mathrm{K}$ dispensers were loaded with 1:2 ethyl acetate/ethanol blend. By contrast, ratio was approximately 2:3 in the samples analyzed from the rest of locations where 1:3 ethyl acetate/ethanol blend was employed to load the $\mathrm{K}$ dispensers.

As mentioned above for ferrugineol trials, RPW captures were in general strongly affected by the factors block and time (date) and the addition of the synthetic kairomone ethyl acetate/ethanol blend (factor trap) to ferrugineol-baited traps also had significant effects on RPW captures (Table 6). In general, traps baited with $\mathrm{ph}+1$ dispenser with the $1: 3$ synthetic kairomone $(\mathrm{ph}+1 \mathrm{~K})$ performed significantly better than ferrugineol alone, improving trap efficacy (Fig. 3). Besides, in most cases, there was no need for a higher emission using 2 kairomone dispensers $(\mathrm{ph}+2 \mathrm{~K})$, as captures obtained were not significantly different from those obtained by using 1 kairomone dispenser ( $\mathrm{P}>0.28$, Tukey HSD tests). On the other hand, the use of ethyl acetate alone did not significantly improve the attractant power of ferrugineol, except in trial K5 (P = 0.014, Tukey HSD test). The 1:3 ethyl acetate/ethanol blend was at least as effective as the reference local co-attractant in trials K1, K4 and K5. In trial K3, neither the 1:2 ethyl acetate/ethanol blend nor ethyl acetate alone achieved improved trapping efficacy compared to the use of ferrugineol alone (Fig. 2- K3), while the local co-attractant molasses+EtAc provided significant increase in RPW catches relative to the rest of the co-attractants tested.

\section{DISCUSSION}

The dose-dependent response of RPW to its aggregation pheromone has been previously reported in the literature. In accordance with Hallett et al., ${ }^{1,6}$ ferrugineol released at $3 \mathrm{mg}$ day $^{-1}$ captured 1.5 times more adults than at $1 \mathrm{mg} \mathrm{day}^{-1}$, but the authors did not test higher emission rates. Later, Rochat and Avand- 
258 Faghih $^{18}$ observed that release rates over $5 \mathrm{mg}^{-1}$ day $^{-1}$ gave no significant differences in RPW attraction.

259 Results reported herein of the trials conducted in Spain (P1 and P2) showed that pheromone emission

260 rates ranging from 4.2 to $12.6 \mathrm{mg} \mathrm{day}^{-1}$ did not significantly affect both female and male RPW responses.

261 Even high emission rates up to $44.6 \mathrm{mg} \mathrm{day}^{-1}$ did not have any significant effect (negative or positive) on

262 weevil captures.

263 Our results were further supported by field trials conducted in different locations in the Mediterranean

264 basin during spring-summer 2014 (trials P3-P6), thus covering varied environmental conditions. But it is

265 precisely for this reason, wide range of microclimate and landscape conditions, that capture data and

266 emission had noticeable variability among experimental sites. Indeed, the distribution of RPW

267 populations is usually clumped and not homogenous, ${ }^{19}$ and it is affected over the year by the availability

268 of hosts and the microclimate conditions of each particular location. Dembilio and Jacas ${ }^{20}$ found a strong

269 relationship between mean annual temperature and the RPW development, which determines the

270 seasonality and the number of generations to be expected in each geographical area. On the other hand, as

271 can be noted in the tables reported, even using common protocols and dispensers, ferrugineol emission

272 varied over a wide range, for instance, from 0.6 to $3.8 \mathrm{mg} \mathrm{day}^{-1}$ in the case of dispenser mod-RF 2 . It is

273 documented that emission rates of dispensers based on polyethylene membranes increased exponentially

274 with temperature ${ }^{21}$ and local temperatures, even at the level of trap (e.g. different insolation), were

275 affecting and causing this variability. In spite of this, analyzing each trial separately, we found that traps

276 baited with the lowest emission rates $\left(0.60-3.85 \mathrm{mg} \mathrm{day}^{-1}\right)$ trapped in general significantly fewer weevils,

277 and increasing emission rates did not improve efficacy (up to $50.92 \mathrm{mg} \mathrm{day}^{-1}$ ). In the global analysis with

278 all the available data (trials P1-P6), the multiple regression analysis did not find a significant quadratic

279 effect of ferrugineol emission on captures; as a consequence, we cannot report an optimum ferrugineol

280 emission rate within the studied range corresponding with a maximum level of captures. Instead, the trend

281 fitted a logarithmic model, in which captures increase rapidly with emission rate up to a threshold (4-5

$282 \mathrm{mg} \mathrm{day}^{-1}$ ) and then slow down reaching a plateau. Thus, trap catches are not reduced above an optimum

283 emission rate, as described for the response to sex pheromones in other insect orders, such as

284 Lepidoptera, ${ }^{22}$ Diptera ${ }^{14}$ or Hemiptera. ${ }^{11}$ Lack of optimum pheromone release rate has already been

285 described for the related species Rhynchophorus palmarum L., the South American palm weevil.

286 Oehlschlager et al. ${ }^{4}$ reported that aggregation pheromone emission could range between $0.3-200 \mathrm{mg}$

287 day $^{-1}$ without significantly affecting $R$. palmarum catches. Actually, antagonistic or saturation effects 
have never been reported to be caused by an aggregation pheromone. For example, the nitidulid beetle Carpophilus hemipterus (L.) responded to its pheromone at all doses between $15-15000 \mu \mathrm{g}$ without significant differences. ${ }^{23}$ Based on our results, although both the emission rate and the response of the weevils were affected by the environmental conditions of each location, we can generally conclude that ferrugineol emission rate can vary in a wide range without affecting significantly RPW catches. Accordingly, any commercial dispenser designed to emit ferrugineol at mean release rates near 4-5 mg day $^{-1}$, will be suitable for RPW trapping systems. Higher release rates do not provide significantly higher captures but have an impact on the longevity of the dispensers and subsequently on the cost of system, as more frequent replacements will be required.

297 As synergizing component of trapping systems, the next step to improve efficacy and optimize cost is to replace the use of natural kairomones. Our results showed that the 1:3 ethyl acetate/ethanol blend suggested in Vacas et al. ${ }^{9}$ is able to improve trap efficacy and perform significantly better than ferrugineol alone, capturing from 2.2 to 1.4 times more total weevils. However, when the ratio was modified to 1:2 (ethyl acetate/ethanol) (trial K3), captures were not significantly improved. Although mean release rates of the blend were similar (Table 4), GC/FID analysis of the remaining content in the dispensers revealed that ethyl acetate/ethanol were emitted in a 2:1 ratio in trial K3 samples, whereas ratio was approximately 2:3 in the rest of the samples analyzed from trials K2, K4 and K5 (same as reported in Vacas et al. ${ }^{9}$ ). This is suggesting the importance of ethanol in the synthetic kairomone blend that should be released even in a higher proportion than ethyl acetate. However, the synthetic blend achieved higher mean captures than ethyl acetate alone but not significantly in all cases, which indicates that blend proportions and dose still need adjustments. The use of molasses as part of the local co-attractants is mainly providing the ethanol needed for the 310 kairomonal effect, whereas palm pieces provide fermenting odors, being ethyl acetate and ethanol the main compounds. ${ }^{8,9}$ Thus, the present work supports the potential of a simple and convenient synthetic co-attractant to improve the efficacy of ferrugineol-baited traps and this is demonstrated on a broader geographical scale than earlier reported. ${ }^{9}$ However, results indicate that the blend still needs optimization.

314 Proportion of compounds in the blend and the dose are crucial to improve trapping performance. More exhaustive studies measuring the ethyl acetate/ethanol quantities and proportions released from the most successful local co-attractants are needed to develop controlled-release dispenser for synthetic 
317 kairomones. This would allow reducing the hand-labor required to service the traps in order to maintain 318 attractant activity and standardize the attractant for monitoring purposes.

319

320 Acknowledgements

321 The research leading to these results has received funding from the 7th European Union Framework

322 Programme under Grant Agreement FP7 KBBE 2011-5-289566 (PALM PROTECT). Authors want to

323 thank Yaakov Nakashe, Ami Landau for field assistance in the trials conducted in Israel, and Gikarakis

324 Dimitrios and Fokas Vlasis in Greece trials. 
1. Hallett RH, Oehlschlager AC and Borden JH. Pheromone trapping protocols for the Asian palm weevil, Rhynchophorus ferrugineus (Coleoptera: Curculionidae). Int J Pest Manag 45:231-237 (1999).

2. Soroker V, Blumberg D, Haberman A, Hamburguer-Rishard M, Reneh S, Talebaev S, Anshelevich L and Harari AR. Current status of red palm weevil infestation in date palm plantations in Israel. Phytoparasitica 33:97-106 (2005).

3. Faleiro JR, El-Saad MA and Al-Abbad AH. Pheromone trap density to mass trap Rhynchophorus ferrugineus (Coleoptera: Curculionidae/Rhynchophoridae/ Dryophthoridae) in date plantations of Saudi Arabia. Int J Trop Insect Sci 31:75-77 (2011).

4. Oehlschlager AC, Chinchilla CC, González LM, Jirón LF, Mexzon R and Morgan B. Development of a pheromone-based trapping system for Rhynchophorus palmarum (Coleoptera: Curculionidae). $J$ Econ Entomol 86:1381-1392 (1993).

5. Vacas S, Primo J and Navarro-Llopis V. Advances in the use of trapping systems for Rhynchophorus ferrugineus (Coleoptera: Curculionidae): Traps and attractants. J Econ Entomol 106:1739-1746 (2013).

6. Hallett RH, Gries G, Gries R and Borden JH. Aggregation pheromones of two Asian palm weevils, Rhynchophorus ferrugineus and R. vulneratus. Naturwissenschaften 80:328-331 (1993).

7. Giblin-Davis RM, Oehlschlager AC, Pérez A, Gries G, Gries R, Weissling TJ, Chinchilla CM, Peña JE, Hallett RH, Pierce HD and González LM. Chemical and behavioral ecology of palm weevils (Curculionidae: Rhynchophorinae). Fla Entomol 79:153-167 (1996).

8. Guarino S, Lo Bue P, Peri E and Colazza S. Responses of Rhynchophorus ferrugineus adults to selected synthetic palm esters: electroantennographic studies and trap catches in an urban environment. Pest Manag Sci 67:77-81 (2011).

9. Vacas S, Abad-Payá M, Primo J and Navarro-Llopis V. Identification of pheromone synergists for Rhynchophorus ferrugineus trapping systems from Phoenix canariensis palm volatiles. J Agr Food Chem 62:6053-6064 (2014).

10. Anshelevich L, Kehat M, Dunkelblum E and Greenberg S. Sex pheromone traps for monitoring the European vine moth, Lobesia botrana: Effect of dispenser type, pheromone dose, field aging of dispenser, and type of trap on male captures. Phytoparasitica 22:281-290 (1994). 
11. Zhang A and Amalin D. Sex pheromone of the female pink hibiscus mealybug, Maconellicoccus hirsutus (Green) (Homoptera: Pseudococcidae): Biological activity evaluation. Environ Entomol 34:264-270 (2005).

12. Vacas S, Alfaro C, Navarro-Llopis V, Zarzo M and Primo J. Study on the optimum pheromone release rate for attraction of Chilo suppressalis (Lepidoptera: Pyralidae). J Econ Entomol 102:10941100 (2009).

13. Vacas S, Alfaro C, Zarzo M, Navarro-Llopis V and Primo J. Effect of sex pheromone emission on the attraction of Lobesia botrana. Entomol Exp Appl 139:250-257 (2011).

14. Navarro-Llopis V, Alfaro C, Primo J and Vacas S. Response of two tephritid species, Bactrocera oleae and Ceratitis capitata, to different emission levels of pheromone and parapheromone. Crop Prot 30:913-918 (2011).

15. O'hara RB and Kotze DJ. Do not log-transform count data. Meth Ecol Evol 1:118-122 (2010).

16. Hothorn T, Bretz F and Westfall P. Simultaneous Inference in General Parametric Models. Biom J 50:346-363 (2008).

17. R Development Core Team. The R Foundation for Statistical Computing. URL http://www.Rproject.org (2014).

18. Rochat D and Avand-Faghih A. Trapping of red palm weevil (Rhynchophorus ferrugineus) in Iran with selective attractants, in Practice oriented results on use and production of neem ingredients and pheromones IV, ed. by Kleeberg $\mathrm{H}$ and Zebitz CPW, Druck \& Graphic, Giessen, Germany, pp. 219-224 (2000).

19. Faleiro JR, Kumar JA and Rangnekar PA. Spatial distribution of red palm weevil Rhynchophorus ferrugineus Oliv.(Coleoptera: Curculionidae) in coconut plantations. Crop Prot 21:171-176 (2002).

20. Dembilio Ó and Jacas JA. Basic bio-ecological parameters of the invasive Red Palm Weevil, Rhynchophorus ferrugineus (Coleoptera: Curculionidae), in Phoenix canariensis under Mediterranean climate. Bull Entomol Res 101:153-163 (2011).

21. Torr SJ, Hall DR, Phelps RJ and Vale GA. Methods for dispensing odour attractants for tsetse flies (Diptera: Glossinidae). Bull Entomol Res 87:299-311 (1997).

22. Vacas S, López J, Primo J and Navarro-Llopis V. Response of Tuta absoluta (Lepidoptera: Gelechiidae) to Different Pheromone Emission Levels in Greenhouse Tomato Crops. Environ Entomol 42:1061-1068 (2013). 

septum age on effectiveness of pheromones for Carpophilus mutilatus and C. hemipterus (Coleoptera: Nitidulidae) in a California date garden. J Econ Entomol 87:667-675 (1994).

387 
Tables

389 Table 1. Description of the experimental areas

\begin{tabular}{|c|c|c|c|c|c|c|}
\hline Country & Location & Coordinates & $\begin{array}{l}\text { Elev. } \\
(\mathrm{m})^{\mathrm{a}}\end{array}$ & Surrounding area & Host palms available & Trial $^{\mathrm{b}}$ \\
\hline Egypt & $\begin{array}{l}\text { Ismaïlia } \\
\text { (Ismaïlia) }\end{array}$ & $\begin{array}{l}30^{\circ} 42^{\prime} 00^{\prime \prime} \mathrm{N} \\
31^{\circ} 48^{\prime} 0^{\prime \prime} \mathrm{E}\end{array}$ & 10 & $\begin{array}{c}\text { date palms and mango } \\
\text { orchards }\end{array}$ & P. dactylifera & $\mathrm{K} 1$ \\
\hline Greece & Lavrio (Attiki) & $\begin{array}{l}37^{\circ} 43^{\prime} 20^{\prime \prime} \mathrm{N} \\
24^{\circ} 3^{\prime} 5^{\prime \prime} \mathrm{E}\end{array}$ & 3 & $\begin{array}{l}\text { urban/rural: great number of } \\
\text { palms in houseyards, } \\
\text { median strips and gardens }\end{array}$ & $\begin{array}{l}\text { mainly } P \text {. canariensis; } \\
\text { few } P \text {. dactylifera, } W . \\
\text { filifera and } C \text {. humilis }\end{array}$ & $\begin{array}{l}\mathrm{P} 3, \\
\mathrm{~K} 2\end{array}$ \\
\hline Israel & $\begin{array}{c}\text { Almagor } \\
\text { (Jordan Valley) }\end{array}$ & $\begin{array}{l}32^{\circ} 54^{\prime \prime} 46^{\prime} \mathrm{N} \\
35^{\circ} 35^{\prime} 54^{\prime \prime} \mathrm{E}\end{array}$ & 3 & $\begin{array}{l}\text { avocado orchards, olive } \\
\text { orchards and open areas. }\end{array}$ & - & P5 \\
\hline Israel & $\begin{array}{l}\text { Rehovot (Center } \\
\text { District) }\end{array}$ & $\begin{array}{l}31^{\circ} 54^{\prime} 24^{\prime \prime} \mathrm{N} \\
34^{\circ} 48^{\prime} 17^{\prime \prime} \mathrm{E}\end{array}$ & 60 & $\begin{array}{l}\text { many scatered palms in } \\
\text { gardens with a variety of } \\
\text { ornamental plants }\end{array}$ & $\begin{array}{c}\text { mainly } P \text {. canariensis } \\
\text { and } P \text {. dactylifera; few } \\
W . \text { filifera and } S . \\
\text { romanzoffiana }\end{array}$ & $\mathrm{K} 3$ \\
\hline Italy & $\begin{array}{l}\text { Grottammare } \\
\text { (Ascoli Piceno) }\end{array}$ & $\begin{array}{l}42^{\circ} 59^{\prime} 20^{\prime \prime} \mathrm{N} \\
13^{\circ} 52^{\prime} 05^{\prime \prime} \mathrm{E}\end{array}$ & 4 & $\begin{array}{l}\text { urban area - scattered palms } \\
\text { and nursery near one of the } \\
\text { plots }\end{array}$ & P. canariensis & K4 \\
\hline Italy & Palermo (Sicily) & $\begin{array}{l}38^{\circ} 06^{\prime} 25^{\prime \prime} \mathrm{N} \\
13^{\circ} 21^{\prime} 07^{\prime \prime} \mathrm{E}\end{array}$ & 43 & urban area/ park & P. canariensis & $\begin{array}{l}\mathrm{P} 4 \\
\mathrm{~K} 5\end{array}$ \\
\hline Spain & $\begin{array}{c}\text { Manises } \\
\text { (Valencia) }\end{array}$ & $\begin{array}{c}39^{\circ} 30^{\prime} 17^{\prime \prime} \mathrm{N} \\
0^{\circ} 30^{\prime} 33^{\prime \prime} \mathrm{O}\end{array}$ & 52 & $\begin{array}{c}\text { industrial/urban area - palm } \\
\text { nursery }\end{array}$ & $\begin{array}{c}\text { mainly } P \text {. canariensis } \\
\text { and } P . \text { dactylifera; also } \\
C . \text { humilis and } W . \\
\text { filifera }\end{array}$ & $\begin{array}{l}\text { P1 } \\
\text { P6 }\end{array}$ \\
\hline Spain & $\begin{array}{c}\text { Valencia } \\
\text { (Valencia) }\end{array}$ & $\begin{array}{l}39^{\circ} 29^{\prime} 2^{\prime \prime} \mathrm{N} \\
0^{\circ} 20^{\prime} 27^{\prime \prime} \mathrm{O}\end{array}$ & 6 & $\begin{array}{l}\text { urban area, gardens and } \\
\text { herbaceous crops }\end{array}$ & $\begin{array}{c}\text { mainly } P \text {. canariensis } \\
\text { and } P \text {. dactylifera; } \\
\text { some } W . \text { filifera }\end{array}$ & $\mathrm{P} 2$ \\
\hline
\end{tabular}

${ }^{\mathrm{a}}$ Elevation (meters above sea level).

$391{ }^{\mathrm{b}}$ Code of the trials carried out at each location (See Tables 2 and 3). 
Table 2. Details of the trials carried out to test different ferrugineol emission rates

\begin{tabular}{cccccccc}
\hline Trial $^{\mathrm{a}}$ & $\begin{array}{c}\text { T mean } \\
\left({ }^{\circ} \mathrm{C}\right)\end{array}$ & $\begin{array}{c}\text { T max } \\
\left({ }^{\circ} \mathrm{C}\right)\end{array}$ & $\begin{array}{c}\text { T min } \\
\left({ }^{\circ} \mathrm{C}\right)\end{array}$ & $\begin{array}{c}\text { RH mean } \\
(\%)\end{array}$ & Start & End & Blocks $^{\mathrm{b}}$ \\
\hline P1 & 22 & 33.3 & 9.2 & 70.7 & $07-09-12$ & $16-10-12$ & 3 \\
P2 & 25 & 36.4 & 13.9 & 70.5 & $26-07-13$ & $20-09-13$ & 4 \\
P3 & 19.3 & 29.7 & 9.3 & 68 & $04-04-14$ & $02-06-14$ & 4 \\
P4 & 22 & 37.6 & 12.3 & 55 & $07-05-14$ & $02-07-14$ & 4 \\
P5 & 27.4 & 40.3 & 9.6 & 57.8 & $14-05-14$ & $09-07-14$ & 4 \\
\hline P6 & 25.1 & 36.6 & 14.9 & 67 & $13-06-14$ & $08-08-14$ & 4 \\
\hline
\end{tabular}

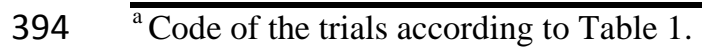

$395{ }^{\mathrm{b}}$ Number of blocks arranged. 

ethyl acetate and ethanol.

\begin{tabular}{|c|c|c|c|c|c|c|c|c|}
\hline Trial $^{\mathrm{a}}$ & $\begin{array}{c}\mathrm{T} \text { mean } \\
\left({ }^{\circ} \mathrm{C}\right)\end{array}$ & $\begin{array}{c}\mathrm{T} \max \\
\left({ }^{\circ} \mathrm{C}\right)\end{array}$ & $\begin{array}{c}\mathrm{T} \min \\
\left({ }^{\circ} \mathrm{C}\right)\end{array}$ & $\begin{array}{c}\text { RH mean } \\
(\%)\end{array}$ & Start & End & Blocks $^{\text {b }}$ & $\begin{array}{l}\text { Local co- } \\
\text { attractant }^{\mathrm{c}}\end{array}$ \\
\hline $\mathrm{K} 1$ & 28.7 & 42.9 & 16.4 & 55 & $08-05-14$ & $10-07-14$ & 4 & $\begin{array}{c}\text { P. dact. }+ \\
\text { molasses }\end{array}$ \\
\hline $\mathrm{K} 2$ & 27.4 & 35.1 & 20.8 & 58 & $26-06-14$ & $22-08-14$ & 4 & - \\
\hline K3 & 27.2 & 40.2 & 10.8 & 64 & $19-08-14$ & 04-11-14 & 4 & $\begin{array}{c}\text { molasses }+ \\
\text { EtAc }\end{array}$ \\
\hline K4 & 16.3 & 26.2 & 6.6 & 81 & $17-09-14$ & $26-11-14$ & 4 & $\begin{array}{l}P . \text { can. }+ \\
\text { molasses }\end{array}$ \\
\hline K5 & 25.1 & 35 & 14 & 56 & 04-08-14 & $13-10-14$ & 4 & $\begin{array}{l}P . \text { can. }+ \\
\text { molasses }\end{array}$ \\
\hline
\end{tabular}

$399{ }^{a}$ Code of the trials according to Table 1.

$400 \quad{ }^{b}$ Number of blocks arranged.

$401{ }^{\mathrm{c}}$ Local co-attractant included in the comparison: (P. dact.) Phoenix dactylifera stem pieces, (P. can.)

402 Phoenix canariensis petioles and/or molasses. Water and co-attractants were renewed every 5 weeks, 403 except in Trial K1 (2 weeks). 
Table 4. Release profiles of the dispensers employed and corresponding mean emission rates of the traps included in each trial

\begin{tabular}{|c|c|c|c|c|}
\hline Trial $^{\mathrm{a}}$ & Dispenser model $^{\mathrm{b}}$ & $\begin{array}{l}\text { no. } \\
\text { units }\end{array}$ & $\mathrm{R}^{2 \mathrm{c}}$ & $\begin{array}{c}\text { Mean } \\
\text { emission } \\
\left(\mathrm{mg} \mathrm{day}^{-1}\right)\end{array}$ \\
\hline \multirow[t]{4}{*}{$\mathrm{P} 1$} & LD-PE vial & 1 & 0.99 & 2.6 \\
\hline & Pherosan RF & 1 & 0.99 & 4.2 \\
\hline & Pherosan RF & 2 & - & 8.4 \\
\hline & Pherosan RF & 3 & - & 12.6 \\
\hline \multirow[t]{4}{*}{$\mathrm{P} 2$} & $\bmod -\mathrm{RF} 1$ & 1 & 0.99 & 5.5 \\
\hline & Pherosan RF & 1 & 0.98 & 11.2 \\
\hline & Pherosan RF & 2 & - & 22.3 \\
\hline & Pherosan RF & 4 & - & 44.6 \\
\hline \multirow[t]{4}{*}{ P3 } & $\bmod -\mathrm{RF} 2$ & 1 & 0.95 & 0.6 \\
\hline & Pherosan RF & 1 & 0.99 & 2.7 \\
\hline & Pherosan RF & 2 & - & 5.4 \\
\hline & Pherosan RF & 4 & - & 10.8 \\
\hline \multirow[t]{4}{*}{ P4 } & mod-RF 2 & 1 & 0.90 & 3.8 \\
\hline & Pherosan RF & 1 & 0.89 & 12.7 \\
\hline & Pherosan RF & 2 & - & 25.4 \\
\hline & Pherosan RF & 4 & - & 50.9 \\
\hline \multirow[t]{4}{*}{ P5 } & mod-RF 2 & 1 & 0.95 & 2.1 \\
\hline & Pherosan RF & 1 & 0.98 & 8.1 \\
\hline & Pherosan RF & 2 & - & 16.2 \\
\hline & Pherosan RF & 4 & - & 32.4 \\
\hline \multirow[t]{4}{*}{ P6 } & $\bmod -\mathrm{RF} 2$ & 1 & 0.98 & 2.6 \\
\hline & Pherosan RF & 1 & 0.99 & 12.6 \\
\hline & Pherosan RF & 2 & - & 25.2 \\
\hline & Pherosan RF & 4 & - & 50.4 \\
\hline \multirow[t]{3}{*}{ K2 } & $\mathrm{K}^{\mathrm{d}}$ LD-PE bottle & 1 & 0.99 & 165.2 \\
\hline & K LD-PE bottle & 2 & - & 330.4 \\
\hline & EtAc LD-PE bottle & 1 & 0.99 & 623.7 \\
\hline \multirow[t]{3}{*}{$\mathrm{K} 3^{\mathrm{e}}$} & K LD-PE bottle & 1 & 0.95 & 133 \\
\hline & K LD-PE bottle & 2 & - & 266 \\
\hline & EtAc LD-PE bottle & 1 & 0.99 & 517 \\
\hline \multirow[t]{3}{*}{ K4 } & K LD-PE bottle & 1 & 0.99 & 110 \\
\hline & K LD-PE bottle & 2 & - & 220 \\
\hline & EtAc LD-PE bottle & 1 & 0.99 & 316.2 \\
\hline \multirow[t]{3}{*}{ K5 } & K LD-PE bottle & 1 & 0.99 & 155 \\
\hline & K LD-PE bottle & 2 & - & 310 \\
\hline & EtAc LD-PE bottle & 1 & 0.99 & 341 \\
\hline
\end{tabular}

${ }^{\text {a }}$ Code of the trials according to Table 1 .

${ }^{\mathrm{b}}$ Dispenser model: (LD-PE vial) 5-ml vial loaded with ferrugineol; (Pherosan RF) standard commercial ferrugineol dispenser; (mod-RF 1) Pherosan RF modified with an adhesive tape coating; (mod-RF 2) Pherosan RF inserted inside a 12-ml LD-PE vial; (K) 100-ml LD-PE bottle loaded with ethyl acetate/ethanol blend; (EtAc) 100-ml LD-PE bottle loaded with ethyl acetate. 
$412{ }^{\mathrm{c}}$ Correlation coefficient of the linear model fitted to weight losses of the unit dispenser with the number 413 of aging days - indicates that the corresponding emission by the number of units is an estimate based on 414 the value for an elementary dispenser.

$415{ }^{\mathrm{d}} \mathrm{K}$ is the synthetic co-attractant composed by a 1:3 (ethyl acetate/ethanol) blend.

$416{ }^{\mathrm{e}} \mathrm{K}$ dispensers were accidentally loaded with 1:2 (ethyl acetate/ethanol) blend in trial K3.

417

418 
Table 5. Results of the trials carried out to compare ferrugineol emission rates: Weevil captures and contribution of the explanatory variables evaluated by analyses of variance using generalized linear models.

\begin{tabular}{|c|c|c|c|c|c|c|c|c|}
\hline Trial $^{\mathrm{a}}$ & $\begin{array}{l}\text { Total } \\
\text { RPW }^{\mathrm{b}}\end{array}$ & $\begin{array}{l}\text { Ratio } \\
\text { F/M }\end{array}$ & Trap & Date & Block & $\begin{array}{c}\text { trap } x \\
\text { date }\end{array}$ & $\begin{array}{l}\text { trap } x \\
\text { block }\end{array}$ & date $\mathrm{x}$ block \\
\hline $\mathrm{P} 1$ & 611 & 1.4 & $\begin{array}{l}\mathrm{F}_{3,42}=7.23 \\
\mathrm{P}<0.001\end{array}$ & $\begin{array}{l}F_{4,42}=14.96 \\
P<0.001\end{array}$ & $\begin{array}{l}F_{2,42}=21.92 \\
P<0.001\end{array}$ & $P=0.26$ & $\mathrm{P}=0.82$ & $\begin{array}{c}\mathrm{F}_{8,42}=2.68 ; \\
\mathrm{P}=0.018\end{array}$ \\
\hline $\mathrm{P} 2$ & 350 & 2.4 & $\begin{array}{l}F_{3,114}=0.19 \\
P=0.91\end{array}$ & $\begin{array}{l}\mathrm{F}_{7,114}=1.86 \\
\mathrm{P}=0.08\end{array}$ & $\begin{array}{l}F_{3,114}=12.13 \\
P<0.001\end{array}$ & $P=0.64$ & $P=0.66$ & $P=0.96$ \\
\hline P3 & 1600 & 2.7 & $\begin{array}{l}F_{3,109}=15.69 \\
P<0.001\end{array}$ & $\begin{array}{l}\mathrm{F}_{7,109}=5.55 \\
\mathrm{P}<0.001\end{array}$ & $\begin{array}{l}\mathrm{F}_{3,109}=9.96 \\
\mathrm{P}<0.001\end{array}$ & $\mathrm{P}=0.12$ & $\mathrm{P}=0.71$ & $\mathrm{P}=0.29$ \\
\hline $\mathrm{P} 4$ & 354 & 1.8 & $\begin{array}{l}F_{3,114}=9.52 \\
P<0.001\end{array}$ & $\begin{array}{l}\mathrm{F}_{7,114}=7.56 \\
P<0.001\end{array}$ & $\begin{array}{l}F_{3,114}=9.75 \\
P<0.001\end{array}$ & $P=0.65$ & $P=0.73$ & $\mathrm{P}=0.84$ \\
\hline P5 & 292 & 1.6 & $\begin{array}{l}\mathrm{F}_{3,85}=0.75 \\
\mathrm{P}=0.53\end{array}$ & $\begin{array}{l}\mathrm{F}_{7,85}=2.23 \\
\mathrm{P}=0.035\end{array}$ & $\begin{array}{l}\mathrm{F}_{3,85}=4.91 \\
\mathrm{P}=0.003\end{array}$ & $\mathrm{P}=0.28$ & $\mathrm{P}=0.11$ & $\begin{array}{c}\mathrm{F}_{21,85}=1.71 \\
\mathrm{P}=0.045\end{array}$ \\
\hline P6 & 285 & 1.9 & $\begin{array}{l}F_{3,112}=6.78 \\
P<0.001\end{array}$ & $\begin{array}{l}\mathrm{F}_{7,112}=2.52 \\
\mathrm{P}=0.02\end{array}$ & $\begin{array}{l}F_{3,112}=15.45 \\
P<0.001\end{array}$ & $\mathrm{P}=0.83$ & $\mathrm{P}=0.14$ & $P=0.52$ \\
\hline
\end{tabular}

422

${ }^{\mathrm{a}}$ Code of the trials according to Table 1.

$423{ }^{\mathrm{b}}$ Total number of weevils captured in each trial (females + males).

$424{ }^{\mathrm{c}}$ Mean ratio females/males $(\mathrm{F} / \mathrm{M})$ of weevils captured in each trial. 
Table 6. Results of the trials carried out to compare various ferrugineol co-attractants including a mixture

427 of ethyl acetate/ethanol: Weevil captures and contribution of the explanatory variables evaluated by

428 analyses of variance using generalized linear models.

\begin{tabular}{|c|c|c|c|c|c|c|c|c|}
\hline Trial $^{\mathrm{a}}$ & $\begin{array}{l}\text { total } \\
\text { RPW }^{\mathrm{b}}\end{array}$ & $\begin{array}{l}\text { ratio } \\
\mathrm{F} / \mathrm{M}^{\mathrm{c}}\end{array}$ & trap & date & block & $\begin{array}{c}\text { trap } x \\
\text { date }\end{array}$ & $\begin{array}{l}\text { trap } x \\
\text { block }\end{array}$ & date $\mathrm{x}$ block \\
\hline $\mathrm{K} 1$ & 810 & 2.1 & $\begin{array}{l}\mathrm{F}_{4,183}=15.2 \\
\mathrm{P}<0.001\end{array}$ & $\begin{array}{l}\mathrm{F}_{9,183}=3.93 \\
\mathrm{P}<0.001\end{array}$ & $\begin{array}{l}\mathrm{F}_{3,183}=2.46 \\
\mathrm{P}=0.06\end{array}$ & $\mathrm{P}=0.84$ & $P=0.27$ & $P=0.93$ \\
\hline K2 & 1795 & 2.3 & $\begin{array}{l}F_{3,114}=3.04 \\
P=0.03\end{array}$ & $\begin{array}{l}\mathrm{F}_{7,114}=1.06 \\
\mathrm{P}=0.39\end{array}$ & $\begin{array}{l}F_{3,114}=2.60 \\
P=0.05\end{array}$ & $P=0.62$ & $P=0.48$ & $\mathrm{P}=0.98$ \\
\hline $\mathrm{K} 3$ & 2100 & 1.4 & $\begin{array}{l}\mathrm{F}_{4,178}=8.72 \\
\mathrm{P}<0.001\end{array}$ & $\begin{array}{l}\mathrm{F}_{9,178}=10.7 \\
\mathrm{P}<0.001\end{array}$ & $\begin{array}{l}\mathrm{F}_{3,178}=18.7 \\
\mathrm{P}<0.001\end{array}$ & $P=0.15$ & $P=0.27$ & $\mathrm{P}=0.44$ \\
\hline K4 & 3059 & 1.8 & $\begin{array}{l}\mathrm{F}_{4,156}=8.10 \\
\mathrm{P}<0.001\end{array}$ & $\begin{array}{l}F_{9,156}=44.8 \\
P<0.001\end{array}$ & $\begin{array}{l}\mathrm{F}_{3,156}=19.1 \\
\mathrm{P}=0.001\end{array}$ & $P=0.06$ & $P=0.07$ & $\begin{array}{c}\mathrm{F}_{27,156}=2.04 \\
\mathrm{P}=0.004\end{array}$ \\
\hline K5 & 830 & 1.6 & $\begin{array}{l}F_{4,183}=10.62 \\
P<0.001\end{array}$ & $\begin{array}{l}F_{9,183}=3.94 \\
P<0.001\end{array}$ & $\begin{array}{l}F_{3,183}=15.1 \\
P<0.001\end{array}$ & $\mathrm{P}=0.37$ & $P=0.46$ & $\mathrm{P}=0.31$ \\
\hline
\end{tabular}

$429{ }^{a}$ Code of the trials according to Table 1.

$430{ }^{\mathrm{b}}$ Total number of weevils captured in each trial (females + males).

$431{ }^{\mathrm{c}}$ Mean ratio females/males $(\mathrm{F} / \mathrm{M})$ of weevils captured in each trial. 
436 Fig. 1 Locations where the field trials have been conducted along the Mediterranean basin. Description of 437 experimental areas and code of trials according to Table 1.

439 Fig. 2 Mean ( \pm SE) number of weevils captured per trap and per day in pyramidal Picusan ${ }^{\circledR}$ traps

440 deployed in the trials P1-P6 (see Tables 2 and 5) aimed at evaluating the dose of ferrugineol emitted. For 441 each trial, bars labelled with the same letter are not significantly different (Tukey HSD tests, $\mathrm{P}>0.05$ ).

443 Fig. 3 Mean $( \pm$ SE) residuals from the ANOVA performed with factors date and location using the whole 444 data set of aggregation pheromone trials (P1-P6). Multiple regression analysis performed to correlate the 445 dependent variable residuals with the factor emission fitted the logarithmic model depicted (discontinuous 446 line; $\mathrm{P}=0.013, \mathrm{R}^{2}=0.51$ ).

447

448 Fig. 4 Mean $\left( \pm\right.$ SE) number of weevils captured per trap and per day in pyramidal Picusan ${ }^{\circledR}$ traps 449 deployed in the kairomone trials: K1-K5 (see Tables 3 and 6) aimed at comparing various ferrugineol 450 (ph) co-attractants. All traps contained ph. The trials included no co-attractant (none), only ethyl acetate 451 (EtAc), a local co-attractant (local C; Table 3; absent in K2), and K: a 1:3 mixture of ethyl acetate/ethanol 452 using 1 or 2 dispensers ( $1 \mathrm{~K}$ and $2 \mathrm{~K}$, respectively). For $\mathrm{K} 3$, the $\mathrm{K}$ dispensers were accidentally loaded with 453 a 1:2 ratio. For each trial, bars labelled with the same letter are not significantly different (Tukey HSD 454 tests, $\mathrm{P}>0.05)$. 